\title{
Consequences of International Migration on the Size and Composition of Religious Groups in Austria
}

\author{
Michaela Potančoková ${ }^{1} \cdot$ Sandra Jurasszovich $^{1}$ • \\ Anne Goujon ${ }^{2}$
}

Published online: 22 May 2018

(C) The Author(s) 2018

\begin{abstract}
Scientific knowledge on a population's religious composition is essential to understand the challenges faced by societies today. It arises in opposition to speculations about the actual size of religious groups that have been increasingly present in the public discourse in Europe for many years. This is particularly the case in Austria where the flows of refugees and migrants coming from the Middle East and Afghanistan have intensified since 2011 and culminated in 2015. These sparked a debate on the actual size of the Muslim population in Austria. This study fills the gap by presenting estimates of the religious composition for 2016 and projections until 2046 based on several scenarios related to the three major forces affecting the religious composition: migration (including asylum seekers), differential fertility and secularisation. The projections demonstrate that religious diversity is bound to increase, mostly through immigration and fertility. We further focus on the role and implications of international migration on the age and sex composition within the six religious groups: Roman Catholics, Protestants, Orthodox, Muslims, other religions and unaffiliated. We find that the volume and composition of international migrants can maintain youthful age compositions in minority religions-Muslims and Orthodox. Sustained immigration leads to slower ageing but does not stop or reverse the process. The disparity between older majority and younger minority religious groups will further increase the cultural generation gap.
\end{abstract}

Anne Goujon

anne.goujon@oeaw.ac.at

1 Wittgenstein Centre for Demography and Global Human Capital (IIASA, VID/ÖAW, WU),

Vienna Institute of Demography/Austrian Academy of Sciences, Welthandelsplatz 2, 1020 Vienna, Austria

2 Wittgenstein Centre for Demography and Global Human Capital (IIASA, VID/ÖAW, WU),

Vienna Institute of Demography/Austrian Academy of Sciences and World Population Programme/ International Institute for Applied Systems Analysis (IIASA), Welthandelsplatz 2, 1020 Vienna, Austria 
Keywords Population projections $\cdot$ Religion $\cdot$ International migration $\cdot$ Austria $\cdot$ Age structure $\cdot$ Sex ratio

\section{Introduction}

Historically, religious identity has been rather a feature of social structure and cultural construct than an individual choice (Hammond 1992). Since the Reformation, Austria has been a Roman Catholic country, with small pockets of Protestant and Jewish populations. This started to change in the first half of the twentieth century with the rise of secularisation as well as with forced migration movements during and after WWII. These trends affected many European countries. Another trend became prominent after the 1950s when labour migration opened western Europe to 'new' religions that had been only marginally represented beforehand, mainly Muslims and Christian Orthodox. Until the first oil crisis in 1973, Austria among other western European countries recruited cheap and unskilled workers to fill labour shortages in the context of booming economies (Messina 2007). These migrants often came through guest worker programmes based on treaties between receiving countries, e.g. Germany and Austria, and sending countries, e.g. Turkey and Yugoslavia, to name a few, or through former colonial ties, like in the case of France with Algeria (Zimmermann 1995). While the first post-WWII economic crisis that followed the 1973 oil crisis put an end to this migration, but this was only temporary as it was followed by more waves of dependents and extended families of this first generation. Religious diversity also increased through migrations that arose from political crises in neighbouring countries such as the Yugoslavian war and after the collapse of the communist regimes in the central and eastern Europe in the late 1980s and early 1990s. Thus, since the mid-twentieth century, international migration has altered, through several distinct flows, the religious landscape of countries and cities across Europe (see Knippenberg 2010 for the Netherlands; Goujon et al. 2007 for Austria; Stonawski et al. 2015 for Spain).

At the same time, Europe was going through another phenomenon: secularisation. In the strict sense of the word, it reflects the fact that some Christian Europeans became atheists or agnostics, but more appropriately, it is used in the broad sense, implying that religion has gradually lost its overarching importance in people's lives and has become more of an individual characteristic. Turner (2011, p. xi) speaks about this phenomenon as 'a 'de-Christianisation' of Europe rather than secularisation, and hence about a 'post-Christian Europe' rather than a secular Europe".

The two phenomena of an increasing number of religious minorities and ongoing secularisation have been very present in Austria, and particularly, since the 1970s, they have upset the previous religious homogeneity: the share of Roman Catholics has declined from 87 to $75 \%$ between 1971 and 2001 (the last time religious affiliation was measured in the census). ${ }^{1}$ During the same period, the share of those without any

\footnotetext{
${ }^{1}$ Since 2001, data on religious affiliation have been no longer available. In 2011, Austria moved to a completely register-based census, not releasing data on religious affiliation. Data on religious affiliation are collected in the Central Register of Residence. However, filling in one's religion in the registration form is not compulsory.
} 
religious affiliation rose from 4 to $12 \%$ and that of the Muslim community rose from nil to $4 \%$.

Both trends of secularisation and religious diversification that are shaping the religious landscape of Austria today can be quantified as data are available to estimate the number of individuals in several large religious categories. Since the last count of religious affiliation in the 2001 census, the enlargement of the European Union has increased migration flows from the neighbouring new member countries, and recently, the Arab spring in 2011 and the wars in Iraq and Syria have caused the displacement of populations from there who fled to neighbouring countries and to Europe. Other conflicts in Afghanistan, Iraq, Eritrea, and dire poverty in further countries lead more people to look for opportunities elsewhere. In 2015, Austria registered more than 88,000 asylum applications - 10.3 per 1000 residents and became one of the major receiving countries of asylum seekers (Migration Policy Institute Data Hub based on Eurostat). It is therefore evident that religious plurality has continued to rise in Austria but to what extent is not known.

We are addressing this gap using mostly demographic methods to assess - from the existing data - the demographic behaviours of the population by religious affiliation (in terms of fertility and migration) as well as the secularisation patterns prevalent in the different religious groups. These data are then used to estimate the current (2016) religious composition of Austria, ${ }^{2}$ employing multistate population projection methodology. Second, we project the religious composition according to narrative scenarios about what possible future development/trends might develop. The work presented here is an extension of previous efforts, with regard to both a refinement of the model and the data used (Goujon et al. 2007; Goujon 2014).

The main output of this work is data on sizes and shares of the six main religious groups-Roman Catholics, Protestants, Christian Orthodox, Muslims, religiously unaffiliated and other religions - in terms of religious affiliation. Religious affiliation captures the 'belonging' dimension of religiosity. ${ }^{3}$ It can be understood as a form of identification representing the cultural background of a person (Bouma 1992). It does not reflect the behavioural dimension nor beliefs that are other important dimensions of religiosity. ${ }^{4}$ In other words, our reconstruction and projections provide estimations regarding confessional categories but due to data limitations do not capture other dimensions. Although religious intensity is important, there are several reasons why the work presented in this article is relevant nevertheless. Scientific knowledge on a population's religious composition is essential to understand the challenges faced by societies today: religion is a social phenomenon (Johnstone 2008). In this sense, quantifying Austria's religious landscapes is not about setting a benchmark for a certain level of religious diversity which would be deemed acceptable or threatening, it is rather about testing what level of religious diversity can be expected when different

\footnotetext{
${ }^{2}$ Within this research, we also looked at the religious landscape in Vienna. We report about this in Goujon et al. (2017).

${ }^{3}$ We acknowledge that religiously affiliated persons differ in terms of their religious commitment, practice and in their religious beliefs; however, these other dimensions of religiosity are not available in the census data and therefore a challenge for future modelling.

${ }^{4}$ In the 2001 Austrian census, respondents were asked for their religious affiliation and could select among several choices (Roman Catholic, Lutheran AB, Reformed HB, Old Catholics, Islam, Jewish, No religion) or write down another religious affiliation not mentioned above.
} 
demographic and secularisation directions are followed. It is, first, a matter of preparedness as several direct implications can be derived from such a study, for instance, addressing the availability of religious teaching in the public schools or availability of places of worship. Second, and more importantly, the necessity to research the religious composition arises in opposition to speculations about the actual size of religious groups that have been very present in the public discourse for the last two decades, and increasingly so. The desirability and handling of a multicultural and religiously pluralist society are topics of debates. ${ }^{5}$ The sizes of secular and religious populations are therefore essential socio-cultural characteristics of a society. In opposition to speculations, the work presented in this article, while sometimes using approximations due to incompleteness of data, follows a scientifically rigorous approach.

In this article, we go beyond the discussion of religious diversity in terms of the sizes of religious groups and focus more specifically on the role and implications of international migration on the age and sex composition within and across religious groups. There is not enough published literature on demographic ageing within specific religious groups and we are aiming to address this gap. The ageing of European populations is well under way and should continue in the future but the pace of ageing would differ across religious groups due to the following main reasons: international migration, population momentum, fertility differentials between religious groups and differences in secularisation. We are particularly interested in addressing the role of international migration because the continuous influx of young immigrants can maintain youthful age composition of some religious groups while others may be ageing at a different pace under different volumes and compositions of migrants with respect to the sending countries. Migrants are usually younger than the general population (Rogers and Castro 1982) and their sex ratio can also vary from the general population. By their differentiated pattern of fertility, they can also impact on the population's age composition.

While the role of immigration in the increasing religious diversity is often and rightly put forward, international migrants, if of the same religious faith as the host country population, can also contribute to the growth of the established religions and may also rejuvenate the stocks of religiously affiliated. We empirically test this possibility.

Last but not least, we ask whether and what migration scenarios can hamper the ongoing secularisation. Kaufmann (2010) argues that international immigration can act as a counter-secularisation force.

The article is organised in the following way. After this introduction, the second section develops the methodology and presents the data used for estimating the religious affiliation of the population in Austria in 2016 and projecting it to 2046. The third section describes the results of the exercise in terms of size and shares of the

\footnotetext{
${ }^{5}$ In Austria as in many European countries, many political campaigns focus on Muslims and Islam. For instance, the Freedom Party of Austria (FPÖ) used the slogan "Islamisierung gehört gestoppt" ('Islamisation needs to be stopped') in its 2017 parliamentary election campaign. Another example is the debate about the publication of a report on Muslim kindergartens in Vienna: allegedly some officials of the Austrian government influenced the text of the study originally developed by the University of Vienna to read more negative, insinuating that Muslim kindergartens oppose integration efforts. [www.bostonglobe.com/news/world/2017 /07/05/austria-muslim-kindergarten-study-reviewed-for-text-changes/RgD14ap1FLvxFYRUUCiB2I/story. html] (accessed on 25/9/2017)
} 
main religious groups in Austria within the next 30 years and looks at the implications of the different scenarios on the population's age and sex structure. We conclude by a discussion that contextualises the results beyond religion per se and suggest other explanatory indicators of variations in demographic behaviour, for instance, educational characteristics of different subpopulations.

\section{Methodology and Data}

This work employs the demographic methodology of multistate population projections (Rogers 1981), which is an extension of the cohort-component approach. In the latter, projections are made by applying fertility, mortality and migration rates to the base-year population divided by age and sex. In the multistate approach, the population is further divided into religious categories to which are also applied fertility, mortality and migration rates. Furthermore, the model is dynamic by having the possibility of transitioning between states, i.e. considering the mobility of people between religious categories. The method is used in two ways: First, we apply the projection modelling to reconstruct the religious composition of the population in Austria in 2016, starting from the base-year in 2001 when the latest data were collected. Second, we use the method to project possible future compositions in 2046 based on four scenarios. We highlight the main features of the methodology and data used. More details can be found in Goujon et al. (2017).

\section{Reconstruction}

\section{Baseline Population by Age, Sex and Religion}

2001 is the last year when data on the religious affiliation of the population in Austria were collected. Thus, the population on January $1,2001^{6}$ by age, sex and six religious affiliations serves as the basis for the reconstruction. The six affiliations ${ }^{7}$ considered in this research are Roman Catholics, Protestants, Orthodox, Muslims, other religions and unaffiliated (i.e. persons with no stated religion).

\section{Migration}

Migration statistics ${ }^{8}$ by Statistik Austria (the national statistical office) comprise data on immigration and emigration to and from Austria by age, sex and country of birth. In the absence of concrete data on the religious denomination of migrants, the 'random

\footnotetext{
${ }^{6}$ The census was collected as of May 15, 2001 and the population numbers for January 1, 2001 by religion, age and sex were derived using Population Analysis Spreadsheets (Arriaga et al. 1994).

${ }^{7}$ While we were able to distinguish between several Christian affiliations (Catholic, Protestant and Orthodox), the data do not allow splitting the Muslim group into denominations such as Sunni and Shia Islam for instance.

${ }^{8}$ Since 2002, migration statistics have been based on administrative registrations and de-registrations derived from the Central Register of Residence. The transition from the previous system to the new one invariably led to a break in the time series. Hence, Statistik Austria provides estimated totals for immigration and emigration for 2001; drawing on these total numbers, the proportional distribution by sex, age and country of birth was estimated based on the year 2002 .
} 
migrant assumption' was used to link migrants with religious affiliations, assuming that migrants have the same distribution as the population in their country of birth. ${ }^{9}$ This assumption is strong as in some instances political oppression, human rights abuse, violent conflict and state failure are essential determinants of (asylum) migration and can be associated with specific subpopulations, including religious minorities (Neumayer 2005). However, in the absence of more precise data or other proxy variables such as the region of origin, ethnicity or education, the random migrant assumption is the best approximation method. The religious compositions in the respective countries of birth are retrieved in two ways: for the most prominent sending countries, we collected up-to-date data on religious distribution from national statistics (census 2011 rounds) whenever these were available. ${ }^{10}$ For other countries, we relied on data published by the Pew Research Center $(2011,2012)$. Based on this information, net migration by age, sex and religious affiliation was computed in 5-year steps for 2001-05, 2006-10 and 2011-15.

\section{Fertility}

Computation of fertility rates by religion requires information, firstly, on the number of live births to mothers by age and their religious affiliation, and secondly, on the number of women of reproductive age (generally 15 to 49 years) by religious affiliation. Statistik Austria collects and publishes data on the religion of mothers of every child born. ${ }^{11}$ However, data on the number of women by age and religion (exposure) are not available. Exposures are therefore derived from the present reconstruction and fertility rates are deduced iteratively for 2001-05, 2006-10 and 2011-15.

\section{Mortality}

The evidence of a relation between religion and mortality is inconclusive. While some studies find religiosity to be associated with better health outcomes (Hummer et al. 2004), others suggest that as more religious people tend to have lower education levels (Glaeser and Sacerdote 2008), they would have worse health outcomes (Groot and Van Den Brink 2007). Moreover, some of the mortality advantage shown in the case of religious minorities originating from migration can often be explained by two considerations. First, the fact that only the healthiest can migrate - the so-called healthy migrant effect - and second that returning migrants to their country of birth at old age-sometimes called the salmon effect-are not removed from the registration system and therefore are still accounted for in the exposure (Klotz and Gisser 2015). Hence, the projections do not take into account mortality differentials. We used the mortality rates by age and sex, available from Statistik Austria, and keep them identical across all religious affiliations.

\footnotetext{
${ }^{9}$ Religious affiliation was inferred from the country of birth rather than citizenship because citizenship can be acquired in the years following the arrival into the country and thus might conceal distinct demographic behaviours of immigrants.

${ }^{10}$ For Bosnia and Herzegovina, Bulgaria, Croatia, Czech Republic, Estonia, Georgia, Germany, Hungary, Republic of Moldova, Montenegro, Poland, Portugal, Romania, Serbia, Slovakia and Switzerland.

${ }^{11}$ Information on the religion of the mother is available from the birth register but contains several deficiencies (Goujon et al. 2017).
} 


\section{Secularisation}

Besides demographic processes, religious change is an important development that can have a significant impact on the religious composition of the population. We do not consider switching between religious affiliations, assuming this phenomenon to be marginal considering the large religious groups that we are observing. However, secularisation - the mobility from any religious affiliation to the unaffiliated groupis an important aspect influencing the size of religious groups. Annual statistics on members leaving the Roman Catholic Church and the Protestant Church exist as those church members are taxed based on their income. We calculate secularisation rates by iteration based on the number of members (exposure) in a given period at the time. ${ }^{12}$ Secularisation rates are disaggregated by age following earlier work (Goujon et al. 2007) and sex following the Gender and Generations Survey (GGS year). There are no official statistics on secularisation for Orthodox Christians and Muslims; we therefore turned to the GGS and estimated probabilities of secularisation.

\section{Projections}

In contrast to our reconstruction of the past, we have no information about the different components of change for the future. Scenarios are commonly used in population projections to show the uncertainty about future developments (van der Heijden 1996). We use projection scenarios to outline possible alternative futures that allow us to explore various hypothetical sizes and compositions of migration flows. In our exploration of the potential future religious composition of Austria's population, prime focus is given to international migration, as Goujon (2014) has shown that migration was among the key drivers shaping the religious landscape in the past. The other determinants - demographics (fertility) and religion (secularisation) - are derived to be consistent with the migration narratives and in agreement with scientific knowledge. To study the effect of international migration, we complement these four scenarios with corresponding zero migration scenarios ${ }^{13}$ to allow for quantification of the impact of international migration on the ageing of religious groups.

The following table (Table 1) gives an overview of the main components of the four narratives, while in the next sections, the assumptions are outlined in more detail.

\section{Migration}

The four migration narratives differ in both the size and composition of immigration and emigration flows.

- The scenario European mobility follows the main scenario of Statistik Austria's population projections (2016) in terms of the volume of migration flows (with

\footnotetext{
12 Secularisation data contain the absolute number of leavers. In order to calculate the rates, we need to derive the exposure every 5 -year period.

${ }^{13}$ In contrast to the Closed-borders scenario, the zero-migration scenarios do not include any migration flows right from the beginning of the projections. Regarding fertility and secularisation assumptions, the zeromigration scenarios correspond to their respective primary narratives. In total, eight scenarios are examined.
} 
Table 1 Scenario narratives in a nutshell

\begin{tabular}{|c|c|c|c|c|}
\hline & $\begin{array}{l}\text { European } \\
\text { mobility }\end{array}$ & Diversity & Closed-borders & High-immigration \\
\hline Migration & $\begin{array}{l}\text { Migration flows } \\
\text { are mostly } \\
\text { composed of } \\
\text { migrants } \\
\text { from Europe }\end{array}$ & $\begin{array}{l}\text { Migrations patterns are } \\
\text { characterised by a } \\
\text { stronger non-European } \\
\text { component compared } \\
\text { to the European mobil- } \\
\text { ity scenario }\end{array}$ & $\begin{array}{l}\text { International } \\
\text { migration } \\
\text { comes to a halt } \\
\text { by } 2021 \text { as } \\
\text { Austria seals its } \\
\text { borders }\end{array}$ & $\begin{array}{l}\text { Austria welcomes large } \\
\text { numbers of migrants, } \\
\text { who come } \\
\text { predominantly from } \\
\text { the Middle East and } \\
\text { North Africa (MENA) } \\
\text { and from sub-Saharan } \\
\text { Africa (SSA) countries }\end{array}$ \\
\hline Fertility & $\begin{array}{l}\text { Medium } \\
\text { convergence } \\
\text { across } \\
\text { religions }\end{array}$ & $\begin{array}{l}\text { Medium convergence } \\
\text { across religions }\end{array}$ & $\begin{array}{l}\text { Fast convergence } \\
\text { across religions }\end{array}$ & $\begin{array}{l}\text { Slow convergence across } \\
\text { religions }\end{array}$ \\
\hline Secularisation & $\begin{array}{l}\text { Secularisation } \\
\text { rates remain } \\
\text { constant }\end{array}$ & $\begin{array}{l}\text { Secularisation rates } \\
\text { remain constant }\end{array}$ & $\begin{array}{l}\text { Increase in } \\
\text { secularisation } \\
\text { rates until } \\
\text { 2026-2031, } \\
\text { then they are } \\
\text { kept constant }\end{array}$ & $\begin{array}{l}\text { Decrease in secularisation } \\
\text { rates until 2026-2031, } \\
\text { then they are kept } \\
\text { constant }\end{array}$ \\
\hline
\end{tabular}

${ }^{a}$ Countries included in the MENA region for this research: Syria, Turkey, Iran, Iraq, Egypt, Algeria, Morocco, Tunisia, Israel, Libya, Lebanon, Saudi Arabia, Jordan, United Arab Emirates, Palestine, Yemen, Kuwait, Oman, Qatar and Bahrain

average numbers of 152,000 immigrants and 116,000 emigrants per year). We further combine the immigration flows with a composition dominated by Europeans with predominantly Christian affiliations and a significant share of unaffiliated persons, similar to the migration patterns observed in Austria in 2006-2010, when migration was restricted by law and the financial and economic crisis reduced labour migration.

- Similar to the European mobility scenario, the projected migration numbers in the Diversity scenario follow the main scenario of Statistik Austria (2016). The religious composition of migration flows, however, refers to the period 20112015 with a rather strong non-European component in immigration: Afghanistan, Syria, Iran and Iraq, countries with an overwhelmingly Muslim population, are among the most prominent sending countries.

- In the Closed-borders scenario Austria seals its borders and international migration comes to a halt by 2021. In the first projection period 2016-2020, the lowmigration scenario of Statistik Austria (2016) serves as a reference for the migration volume (with average numbers of 152,000 immigrants and 105,000 emigrants per year until 2020), with the flows being composed of a considerable share of immigrants from non-European countries, similar to what was observed in 20112015.

- In the High-immigration scenario, Austria is more permissive to immigration and the number of immigrants follows the High-immigration scenario of Statistik Austria (2016) which projects a migration volume with average numbers of 182,000 immigrants and 124,000 emigrants per year-numbers which are 
substantially higher than in the past (128,000 immigrants and 85,000 emigrants on average per year between 2001 and 2015). The additional immigration numbers compared with the trend in 2011-2015 are assumed to originate from Middle East and North Africa (MENA), and sub-Saharan African (SSA) countries.

\section{Fertility}

The three fertility narratives differ in their pace of convergence across religious groups. The convergence hypothesis is in line with the literature looking at religious differentials across successive generations of migrants (Coleman 1994; Mayer and Riphahn 2000; Dubuc 2012; Kulu et al. 2017).and consequences of skewed sex ratios The convergence assumption results in a substantial fertility decline among Muslims, while there is a minimal fertility increase for all other religious groups. As to the overall fertility of the total population, we follow the main scenario in the population projection of Statistik Austria (2016).

- The European mobility scenario and the Diversity scenario are linked to the medium-convergence narrative meaning that the TFRs of women across all religious groups would converge in 2071-2075 to a level of 1.59 children per woman.

- The Closed-borders scenario is combined with the fast-convergence narrative where we assume the same TFRs for all women as early as 2046-2050. This scenario results in the lowest fertility level for Muslims and highest for other religious groups to a level of 1.57 children per woman.

- The High immigration scenario is paired with the slow-convergence narrative, which entails the convergence of TFRs for all women only in 2100 to a level of 1.60 children per woman.

\section{Mortality}

Similar to the approach adopted for the reconstruction, mortality rates across religious affiliations are kept identical. The overall mortality rates by sex are based on the medium scenario of Statistik Austria which has life expectancy at birth increasing to 84 years for men and 88 years for women by 2041-2045.

\section{Secularisation}

We assume the share of the population who would move out of their present affiliation to be linked with the immigration scenario: an increase in religious diversity due to high migration would lower secularisation patterns, for religion would become more relevant as an identity marker in a possibly more fragmented society. On the contrary, low migration patterns would accelerate secularisation trends.

- In the scenarios European mobility and Diversity, we assume constant secularisation rates based on the estimates for 2011-2015 until the end of the projection period. 
- $\quad$ The Closed-borders scenario includes a general increase in secularisation rates (+ $10 \%$ per period) until 2026-2031 after which the rates are kept constant until the end of the projection period.

- In the scenario High-immigration, we assume a general decrease in secularisation rates ( $-10 \%$ per period) until 2026-31, with the rates staying constant afterwards.

\section{Results}

\section{Diversity Driven by Immigration: Changing Religious Landscape in Austria}

Since the 2001 census, the changing migration flows regarding countries of birth had an impact on the religious composition of immigrants to Austria. In the first decade of twenty-first century, the main countries of origin were Germany and eastern European countries, i.e. countries with predominantly Christian or religiously unaffiliated populations (Table 2). Although there had been sizeable numbers of Muslim immigrants before - especially from Turkey - a significant change in the patterns of migration flows took place in the periods from 2011 to 2015 with more immigrants from Syria and Afghanistan, both countries with overwhelmingly Muslim populations, joining the top-ten list of sending countries to Austria for the first time. During the same period, the share of the foreign-born population increased from $12.5 \%$ in the 2001 census to $18.2 \%$ as of 1 January 2016 (Eurostat online database). The change in size and composition depicts the rapid changes of the past 15 years: the fraction of the European ${ }^{14}$ foreignborn population declined between 2001 and 2016 from $74 \%$ to about $57 \%$ of the foreign-born.

As a result, the reconstructed population of 2016 by religion shows noticeable changes since the last measurement in 2001 (Fig. 1): the secularisation trend has continued, and the share of Roman Catholics has declined further from 3/4 of the population in 2001 to $2 / 3$ in 2016 . The largest absolute gains were among the unaffiliated (17\% of the population in 2016 compared to $12 \%$ in 2001). The Orthodox and Muslim communities have also grown substantially: the share of Orthodox has more than doubled from 2 to $5 \%$, and Muslims have increased their share from 4 to $8 \%$ between 2001 and 2016. The relative shares of Protestants and other religions remain unchanged.

All four projection scenarios confirm that religious homogeneity would further diminish. The share of Roman Catholics would most likely drop below $50 \%$ by 2046. However, in all scenarios, Roman Catholics would still be the largest religious group in Austria, accounting for $42 \%$ in the High-immigration scenario and $47 \%$ in the Closed-borders scenario. High immigration would result in the largest religious diversity with a smaller representation of both Roman Catholics and unaffiliated persons. All scenarios show an increase in minority religions (Muslims and Orthodox), composed mainly of immigrants. The strong European immigration component in the European mobility and Diversity scenarios would

\footnotetext{
${ }^{14}$ EU-15, former Yugoslav republics, Romania, Poland, Switzerland, Czechia, Slovakia, Hungary; not including ex-USSR countries.
} 
Table 2 Immigration from abroad to Austria: top-10 countries of birth and the number of immigrants in the respective periods

\begin{tabular}{|c|c|c|c|c|c|}
\hline \multicolumn{2}{|l|}{$2001-2005$} & \multicolumn{2}{|l|}{ 2006-2010 } & \multicolumn{2}{|l|}{$2011-2015$} \\
\hline Germany & 58,726 & Germany & 86,947 & Germany & 85,194 \\
\hline Serbia and Montenegro & 54,312 & Romania & 44,317 & Romania & 77,819 \\
\hline Turkey & 48,940 & Hungary & 25,407 & Hungary & 61,218 \\
\hline Bosnia and Herzegovina & 29,791 & Poland & 25,239 & Serbia & 39,495 \\
\hline Romania & 26,704 & Turkey & 24,915 & Poland & 36,489 \\
\hline Poland & 24,296 & Slovakia & 19,887 & Bosnia and Herzegovina & 36,187 \\
\hline Russian Federation & 18,911 & Bosnia and Herzegovina & 18,927 & Syria & 34,977 \\
\hline Hungary & 15,177 & Serbia & 15,702 & Afghanistan & 31,971 \\
\hline Slovakia & 14,741 & Serbia and Montenegro & 14,190 & Slovakia & 29,422 \\
\hline Croatia & 10,912 & Russian Federation & 12,946 & Turkey & 21,179 \\
\hline
\end{tabular}

Source: Statistik Austria

Note: Serbia and Montenegro dissolved in 2006; however, they were pooled together in migration statistics until 2007 and counted separately only from 2008 onwards. Austrians returning back to the country after having lived abroad are one of the largest groups ranking within the top three countries of birth in all three periods. However, since this group is not in the focus of migration policy measures, it is not displayed in Table 2.

result in the fastest growth of the Orthodox to about $9 \%$ of the Austrian population, while in the High-immigration scenario, Muslims would become the second largest religious group in Austria, on a par with the unaffiliated at $21 \%$. The increase in Muslim population would be slightly smaller in the Diversity scenario. The Muslim population has already experienced a sharp growth, from around 4\% in 2001 to $8 \%$ in 2016, and the most recent immigration wave with strong Syrian and Afghani population components has contributed to the sharp increase compared to previous years.

The High-immigration scenario illustrates how significant immigration flows may work against the secularisation trend. The high influx of immigrants from societies where religion is still highly relevant would depress the relative share of the unaffiliated, unless the immigrants themselves secularise at a similar rate as the host population. ${ }^{15}$ In contrast, secularisation has a stronger impact on religious change in the Closed-borders scenario, projecting the highest share of unaffiliated persons (28\%). The share of other religions (mainly Hindus, Buddhists and Jews) is estimated to remain at the same level as in 2016 (about 2\%) across all four scenarios. This is the result of the scenario assumptions envisaging mainly a diversification of religions in Austria to occur through the expansion of already established and growing religious communities such as Orthodox and Muslims, coming from a set of presently sending countries.

\footnotetext{
${ }^{15}$ However, results from the Gender and Generations Survey show lower secularisation rates among the Muslims and Orthodox compared to Roman Catholics and Protestants.
} 


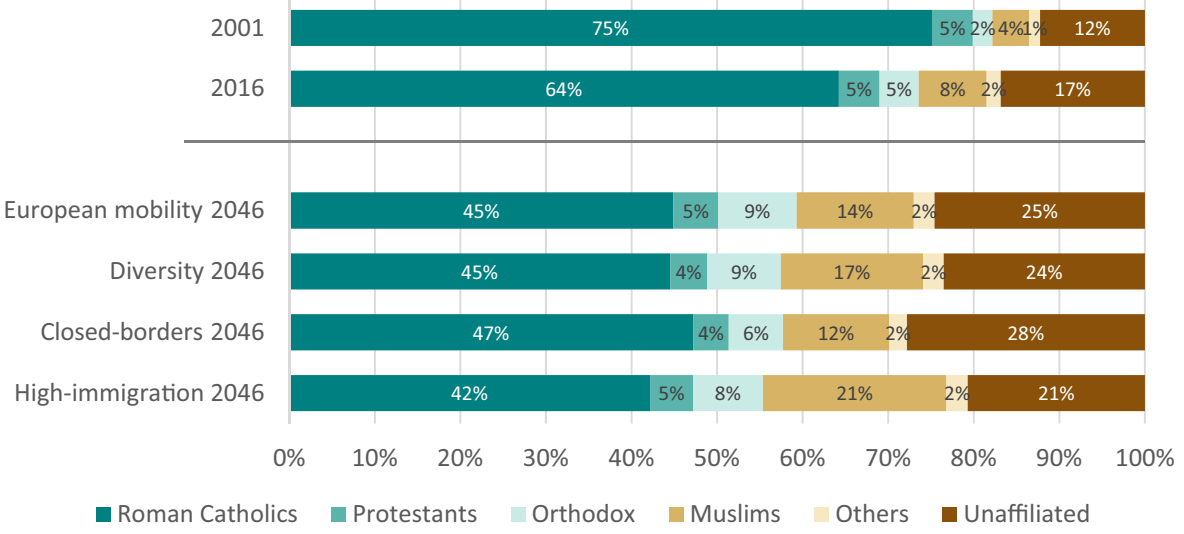

Fig. 1 Religious composition in Austria, 2001-2046. Source: Statistik Austria, authors' calculations

\section{Immigration of Limited Importance for Slower Population Ageing and Only for Smaller Religious Groups}

The vitality of religious communities does not only depend on group size ${ }^{16}$ but also on the age composition. Youthful religious groups have more potential for further growth. To study the age impact of different scenarios at the level of religious affiliations, we split the population into three age groups: 0-34 (young), 35-64 (middle age), and 65+ (elderly). Population ageing will be a reality for all religious groups in Austria, and the share of the elderly population would grow among all religious groups in all scenarios. In this sense, population ageing is inevitable and could not be reversed under the envisaged scenarios. However, immigration could alter the pace of ageing and slow down the decline in the share of the young population.

The projection results show that this would be true for minority religious groups that are already composed mainly of immigrants - Muslims and Orthodox-but also for Protestants who were the religious group with the highest share of elderly people in $2016(27 \%)$ (see Fig. 2, blue lines for the share of elderly persons).

In all but the Closed-borders scenario would the share of young Orthodox increase by 5-10 percentage points (pp) compared to a scenario with zero migration (Fig. 2). Furthermore, the share of elderly Orthodox would stay below $15 \%$, and the share of young Orthodox would drop below 50\% just after 2031 in all except the Closedborders scenario. The Muslim population, however, would fall below 50\% only in the case of the Closed-borders scenario. The age structure of Muslims would remain very young, with about $65 \%$ of the population in the $0-34$ age group. However, the share of the elderly Muslim population would also increase, from 4\% in 2016 to about $10 \%$ in 2046 in all but Closed-borders scenario (16\%) as generations of the early migration waves grow older.

Among all religious groups, international migration has the most significant effect on the age structure of Protestants. Between 2001 and 2016, the share of young Protestants declined from 40 to $36 \%$. The several scenarios with their diverse migration

\footnotetext{
${ }^{16}$ In particular on the numbers of practicing members that are also a function of the number of nominal members.
} 

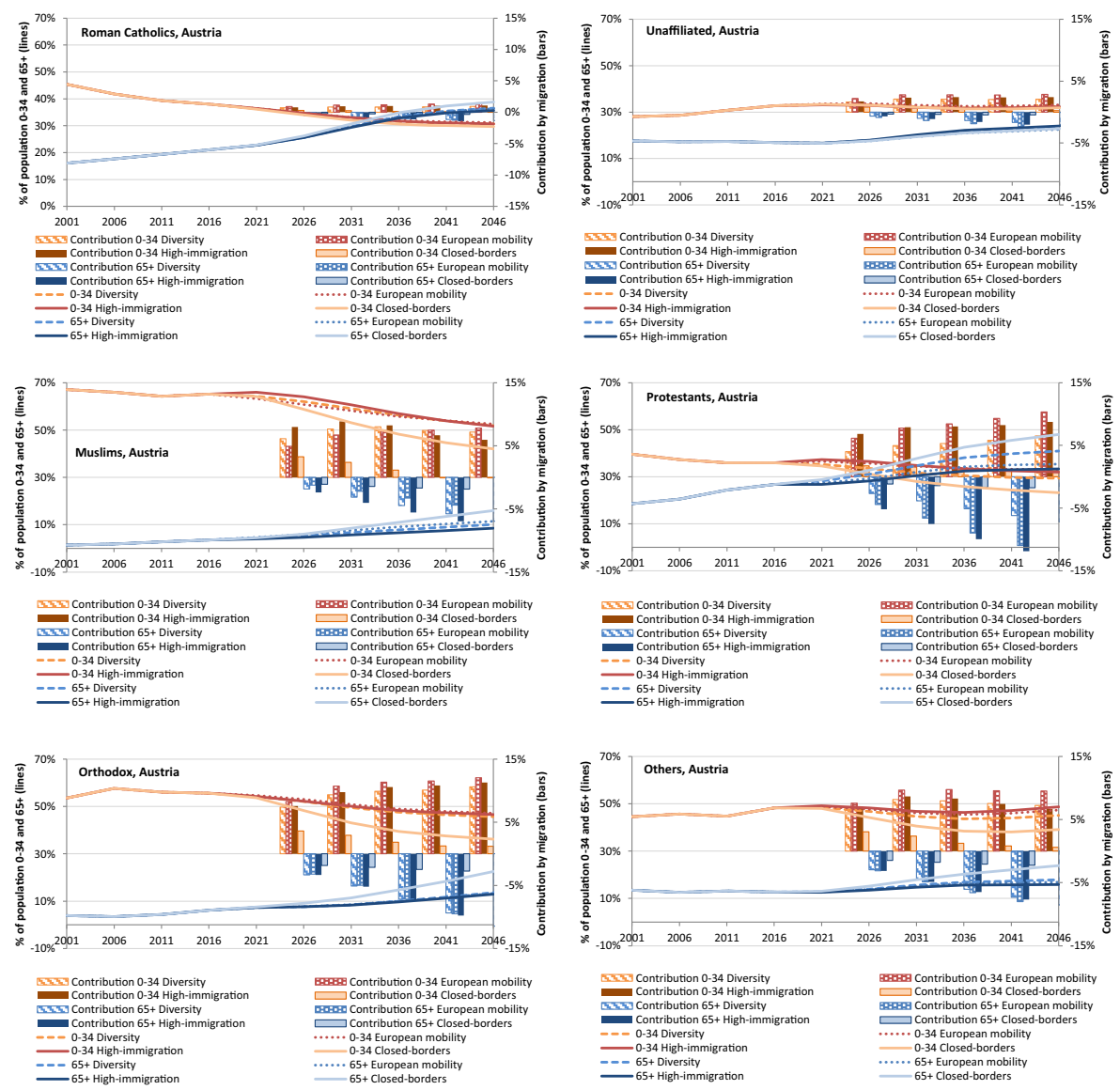

Fig. 2 Observed, estimated and projected shares of population 65+ (blue lines), 0-34 (red lines) and contribution of immigration to these shares (bars), by religious group for 2001-2046. Source: authors' calculations. Note: The contribution (secondary axis) is the difference in the share of population $65+(0-34)$ in the scenario with and in absence of international migration

flows and compositions lead to very different futures. Except for the Closed-borders scenario, immigration would raise the share of young Protestants (age 0-34) by about 5-10 pp until 2046, and lower the share of elderly (65+) by 7-13 pp in 2046 (difference in shares between zero migration scenario and scenarios with migration, see bars in the chart). The Closed-borders scenario would lead to very fast population ageing, and nearly $50 \%$ of Protestants in Austria would be $65+$ in 2046 . The European mobility and High-immigration scenarios would slow down the increase in the proportion of $65+$ age group to 35 and 33 pp, respectively. These two scenarios would also lead to a sustained, and in the first years even slightly increased, share of young members.

Although the European mobility and the High-immigration scenarios would both sustain a younger Protestant population than in the absence of migration, there is a substantial variation in the diversity within the Protestant group. While the European mobility scenario would bring in mostly new Protestants from long-established Evangelic churches (such as Lutherans and Calvinists), the High-immigration scenario 
would potentially greatly diversify the Protestant community. More than $50 \%$ of all Christians in sub-Saharan Africa are Protestants, and many of them are Pentecostals, Anglicans or belonging to African independent churches (PEW 2011). Thus, this scenario would be likely to lead to the emergence of new or hitherto little represented Protestant churches, meaning that the Protestant population in Austria would become more heterogeneous. It may lead to the situation when traditional, historically established Protestant churches would face intense ageing, while the new churches would grow as they would be composed of young and largely foreign-born believers. This scenario would greatly diversify the Christian communities in Austria and affect the position of the long-established, traditional churches.

If we study Roman Catholics, the second oldest religious group in Austria after the Protestants, we see that immigration has little effect on the rejuvenation of their age structures. All four scenarios lead to very similar estimated shares of the young and old. This applies even to the European mobility scenario that would bring in more immigrants from countries with high shares of Roman Catholics. A strong influx of immigrants from sub-Saharan Africa like under the High-immigration scenario would not increase the share of young Roman Catholics because Christians from this region are rather a mixed group of different Christian churches, not necessarily belonging to the Roman Catholic denomination. Thus, the share of elderly Roman Catholics would increase to $36-39 \%$ (up from $16 \%$ in 2001 and $21 \%$ in 2016), and the share of the $0-34$ age group would drop from $45 \%$ in 2001 to about $31 \%$ in 2046 . Thus, the effect of immigration on the age composition (measured as differences in shares between the migration scenarios and zero migration scenarios) is very limited: in all scenarios, immigration raises the share of the young only by about $1 \%$ and depresses the share of the elderly to $1-2 \%$. However, the Closed-borders scenario would lead to Roman Catholics ageing most quickly.

Similarly, the unaffiliated are not affected much by the different scenarios in their estimated trajectories of population ageing. The effect is only slightly more pronounced for Roman Catholics. Between 2001 and 2016, population ageing has been rather stable and the share of young persons increased from 28 to $33 \%$, mostly due to ongoing rapid secularisation, and by 2046, the share is expected to remain very stable, at about 33$31 \%$. The share of the population $65+$ is, however, bound to increase from currently about 17 to $23 \%$. As expected, the European mobility scenario with the highest influx of religiously unaffiliated immigrants across all scenarios would make the greatest difference, raising the share of the young by about $2.7 \%$ while depressing the increase in $65+$ by up to $2.5 \%$.

\section{Intense Immigration Can Offset Sex Balance for Some Religions}

The findings show that immigration could have a stronger effect on sex balance than on the age composition of the religious groups. Sex ratio changes with age: in western Europe, about 105 boys are being born for every 100 girls. Subsequently, differential mortality alters the sex ratio, and with increasing age, we typically find more women in human populations (Coale 1991). Immigration and emigration also impact on the age composition of adult populations, depending on the sex and age composition of the flow that can vary for different groups of migrants. In Austria, immigrants from European countries arriving in 2005-2009 were predominantly women, while asylum 
seeker flows of 2015 were male-dominated. In addition, secularisation rates that have been stronger for men than for women in Austria could also impact the sex balance in religious groups.

We focus in this section on the sex ratio among 20-34-year-olds rather than among the total population. The sex ratio in young adulthood is of particular importance because it is the time of family formation, especially so for the groups with high homogamy, such as ethnically and religiously different migrants. This is particularly the case for Muslims and Hindus in Europe (Lucassen and Laarman 2009). Lack of potential spouses may result in further migration on the basis of family reunification pressure if intermarriage is not socially approved and social ties to the communities of origin remain strong (Carol et al. 2014).

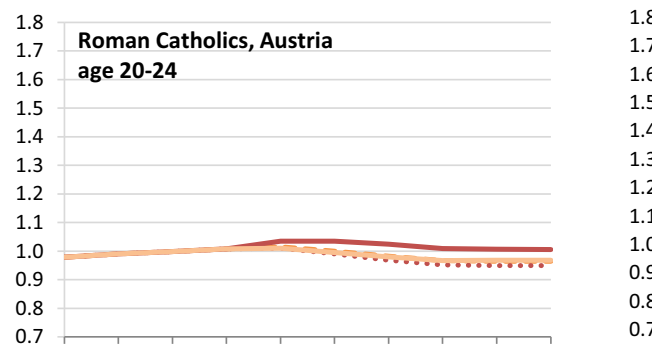

2001200620112016202120262031203620412046 - - - Diversity $\quad$...... European mobility High-immigration Closed-borders


Unaffiliated, Austria age 20-24

2001200620112016202120262031203620412046 - - - Diversity ...... European mobility

High-immigration Closed-borders
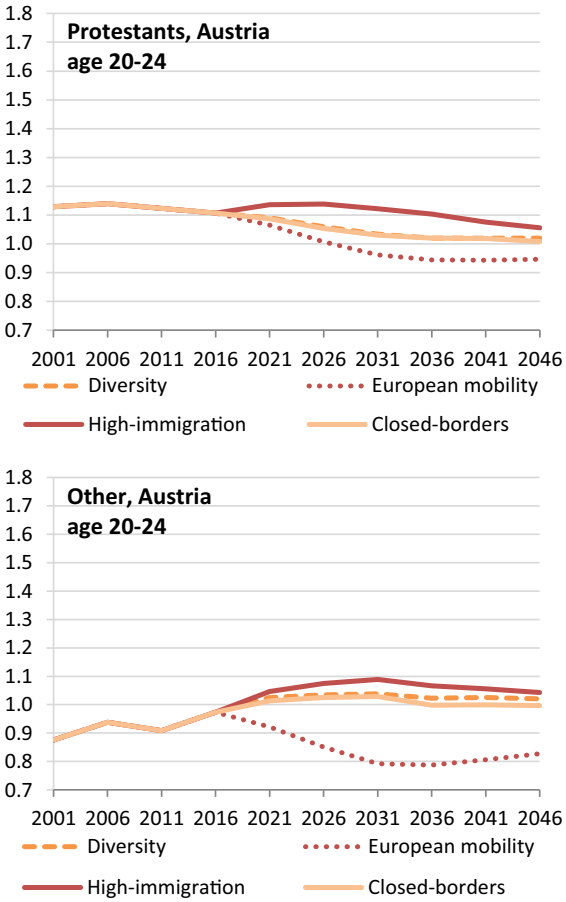

Fig. 3 Observed, estimated and projected sex ratio (number of males to 100 females) for the population aged 20-34 by religious group and scenario, 2001-2046. Source: authors' calculations 
Only Roman Catholics show a nearly balanced and unchanging sex ratio at age 2034 through the whole period of observation from 2001 to 2046, regardless of the scenario, while gender balance is less common among the other religious affiliations. Between 2001 and 2016, women were more numerous among the Orthodox, while there were more men among Muslims, Protestants and the unaffiliated (Fig. 3).

The sex ratio of the Muslim population is exceedingly sensitive to the composition of immigration flows. Due to male-dominated migration flows, the sex ratio for the Muslim population has increased from an only slight (about 113 men per 100 women over the 2001-2011 period) to a more pronounced male dominance in 2016 (130 men per 100 women). Would the sex composition of migrants remain the same as in the period 2011-2015 (Diversity scenario), the sex ratio for Muslims would further increase and exceed 150 men per 100 women by 2031. In the High-immigration scenario, the imbalance in the sex ratio is even more pronounced. Only the European mobility scenario, with higher proportions of women among immigrants, would lead gradually to a more balanced sex composition among Muslims in the next decades.

By contrast, more women could be found among the Orthodox and others during 2001-2016, with a trend towards more gender-balanced composition among 20-34year-olds. For the Orthodox, the Closed-borders scenario would yield the fastest trend towards gender balance, while the European mobility scenario would offset the balance to about $80-85$ men per 100 women.

The sex composition of Protestants may change from a slight male surplus (1.13 to 1.11 in 2001-2016) to a female majority under the European mobility scenario, while the Diversity and Closed-borders scenarios would gradually lead to a balanced sex composition. Only the high influx of immigrants envisaged in the High-immigration scenario would reverse the trend towards a more male-dominated sex composition.

In contrast, the unaffiliated used to be a group with more men of 20-34 years than women-133 per 100 in 2001 (about same as estimated for Muslims in 2016), due to higher secularisation rates among men. By 2016, these groups became more genderbalanced (109 men per 100 women), but only the High-immigration scenario would result in a true sex balance.

\section{Discussion and Conclusion}

While the projections demonstrate some of the possible situations that Austria could experience in the future, and those are all quite dissimilar, they also show that religious diversity is bound to increase while religious homogeneity will be diminishing. The split between the religiously affiliated and unaffiliated population might be less and less relevant - although it might have implications as the unaffiliated tend to be less prone to vote for populist political parties for instance (Marzouki et al. 2016) - and it might be more the co-existence of different religious groups that will require the attention of the various stakeholders. In addition, volatile migration trends that bring together a mix of people from new ethnicities and cultural traditions will further diversify the religious traditions within some religions and lead to a super-diversity of transnationally connected and socio-economically diversified immigrants (Vertovec 2007). These observations are in line with the post-secular theory_-see Kaufmann (2010). 
The Austrian situation is not unique in Europe and most western European countries are undergoing similar experiences. Profound transformations of Europe's religious landscape have been referred to as a 'soft revolution' (Goujon 2014; Goujon and Bauer 2015) - revolution because it affects Christianity which has long been considered the 'foundation of a common European identity' (Halman and Riis 2003, p. 1) and soft because it is neither violent or sudden, nor is it an organised movement but rather a development that progresses gradually but surely through different societal mechanisms. On the one hand, many Europeans have a low sense of religious belonging, having become secularised or turned towards various forms of diffuse religiosity (Cipriani 2017). On the other hand, religious diversity is on the rise, as during the last decades, many European countries have become major receivers of international immigrants who often have a different religion, raising important challenges for how European policymakers manage cultural diversity and accommodate minorities. The increasing number of international migrants, including their descendants, is the main driver of socio-demographic, cultural, ethnic and religious diversity in destination countries, where new arrivals have come with an array of religious denominations that previously had often been just marginal or non-existent.

Our second research question referred to the consequences that international migration to Austria will have on secularisation. The presented scenarios confirm the power of demographic change on the slow-down of secularisation (Kaufmann 2010; Hackett et al. 2015). The high-migration scenario leads to a $7 \mathrm{pp}$ slower rise of the religiously non-affiliated group.

Third, we addressed the effect of international migration on the pace of the ageing process within religious groups. The groups composed largely of previously arrived migrants are bound to age unless they have high fertility. As expected, we find that the volume and composition of international migrants can maintain youthful age compositions in minority religions-Muslims and Orthodox. Sustained immigration leads to slower ageing; however, not even high immigration can stop or even reverse the process. Youthful age structures could help in maintaining the vitality and collective vision of religious groups (Eisenstadt 1956) and sustain future growth if a large proportion of the population are in childbearing age and have relatively high fertility preferences (McQuillan 2004).

Interestingly, we find much stronger an implication of high immigration on the sex composition than on the age structures. High immigration may lead to skewed sex ratios (Dyson 2012) and influence the actual reproductive potential if the sex balance is not achieved among the people of childbearing age. Imbalanced sex ratios may even lead to additional migration if religion is an essential characteristic for the marriage partner, intermarriage is rare and ties to the home communities remain strong.

The decline in group size and the ageing process of the majority religious group, i.e. Roman Catholics, contrasts with the experience of the more rapidly growing minority religions. With higher fertility and greater immigration, the groups of the Muslims and the Orthodox will not age nearly as rapidly as the Roman Catholics. The disparity between older majority and younger minority religious groups will further increase the cultural generation gap with implications for public spending, voting preferences and political representation, to name but a few. Our results, however, also emphasise that the elderly population that is now religiously more homogeneous than the younger cohorts, will increase in religious diversity. In 2016 , only $3 \%$ of the population $65+$ in 
Austria were Muslims or Orthodox. In 2046, this number will range between 10 and $11.5 \%$, depending on the scenario. The experience from the already ageing migrants who came as 'guest workers' to western Europe shows that many stay and do not return to their home countries like the guest worker policies originally envisaged. The social services for elderly people will have to adapt to the increasing religious diversity of the elderly population and distinct cultural traditions embedded in these newly emerging religions. Further research is needed to address the challenges arising from possible cumulative disadvantages caused by a combination of age, gender, migration status, ethnicity (Mutchler and Burr 2011) and religion.

This paper has several recognised limitations. First of all, we look at large religious groups, e.g. Muslims which may hide the de-facto heterogeneities between the many existing religious denominations. Another caveat is that the projections and their analysis do not inform about the level of religiosity of the affiliated. Religiosity is important inasmuch as it indicates the level of adherence of members, which delineates some of their demographic behaviours. Moreover, religiosity varies between natives and first-generation immigrants as well as among immigrants. It has been shown that people belonging to minority religions tend to have a higher level of religious intensity in order to strengthen their selfidentity, but also they often come from countries where religion remains important in shaping the social life and religiosity is stronger in terms of beliefs and practice. At the same time, descendants of immigrants (the second generation) usually show a general convergence towards the religious intensity levels and demographic behaviours of the host society (Inglehart and Norris 2009). However, modelling and projecting religiosity is even more complex than modelling religious affiliation. Data are harder to come by as they are usually collected by small sample surveys that tend to undersample minority and migrant religions. There are also certain problems about choosing indicators that reflect the level of religiosity in the same way for all religions, and that are not too volatile. While projections of both religiosity and religious affiliation exist (Stonawski et al. 2015; Kaufmann et al. 2010), they imply making even more challenging assumptions about the future. The last but not least limitation is that religion hides many other individual variables that can be essential for future developments. Other socio-cultural and socio-economic characteristics, such as nativity status, country of origin, educational attainment or labour force participation, may be underlying factors of demographic behaviour, particularly fertility in some religious groups. For instance, evidence from census 2001 in Austria shows that the fertility of Muslim women in Austria is high because many have low education. However, those Muslim women who are highly educated have similar fertility outcomes as highly educated Roman Catholic women in Austria (Goujon et al. 2017).

Funding Information Open access funding provided by International Institute for Applied Systems Analysis (IIASA). The research presented in this article received financial support from the Austrian Integration Fund (ÖIF).

Open Access This article is distributed under the terms of the Creative Commons Attribution 4.0 International License (http://creativecommons.org/licenses/by/4.0/), which permits unrestricted use, distribution, and reproduction in any medium, provided you give appropriate credit to the original author(s) and the source, provide a link to the Creative Commons license, and indicate if changes were made. 


\section{References}

Arriaga, E.E., Johnson, P.D., Jamison, E. (1994) Population analysis with microcomputers, volume II software and documentation. Washington, DC: U.S. Census Bureau.

Bouma, G. D. (1992). Religion: meaning, transcendence and community in Australia. Melbourne: Longman Cheshire.

Carol, S., Ersanilli, E., \& Wagner, M. (2014). Spousal choice among the children of Turkish and Moroccan immigrants in six European countries: transnational spouse or co-ethnic migrant? International Migration Review, 42(2), 387-414.

Cipriani, R. (2017) Diffused religion: beyond secularisation. Springer. ISBN 978-3-319-57894-1.

Coale, A. (1991). Excess female mortality and the balance of the sexes in the population: an estimate of the number of "missing females". Population and Development Review, 17(3), 517-523.

Coleman, D. A. (1994). Trends in fertility and intermarriage among immigrant populations in Western Europe as measures of integration. Journal of Biosocial Science, 26(1), 107-136.

Dubuc, S. (2012). Immigration to the UK from high-fertility countries: intergenerational adaptation and fertility. Population and Development Review, 38(2), 353-368.

Dyson, T. (2012). Causes and consequences of skewed sex ratios. Annual Review of Sociology, 38, $443-461$.

Eisenstadt, S. N. (1956). From generation to generation: age groups and social structure. New Brunswick: Transaction Publishers.

Glaeser, E. L., \& Sacerdote, B. I. (2008). Education and religion. Journal of Human Capital, 2(2), 188-215.

Goujon, A. (2014). WIREL project key findings: religions in Vienna in the past, present and future. Vienna: Vienna Institute of Demography.

Goujon, A., \& Bauer, R. (2015). Demographic forces shaping the religious landscape of Vienna. In S. D. Brunn (Ed.), The changing world religion map: sacred places, identities, practices and politics (pp. 2145-2161). Dordrecht: Springer.

Goujon, A., Skirbekk, V., Fliegenschnee, K., \& Strzelecki, P. (2007). New times, old beliefs: projecting the future size of religions in Austria. Vienna Yearbook of Population Research, 5, 237-270.

Goujon, A., Jurasszovich, S., \& Potančoková, M. (2017). Religious denominations in Vienna \& Austria: baseline study for 2016 — scenarios until 2046. In VID working paper 9/2017. Vienna: Vienna Institute of Demography.

Groot, W., \& Van Den Brink, H. M. (2007). The health effects of education. Economics of Education Review, 26(2), 186-200.

Hackett, C., Stonawski, M., Potančoková, M., Grim, B. J., \& Skirbekk, V. (2015). The future size of religiously affiliated and unaffiliated population. Demographic Research, 32(27), 829-842.

Halman, L., \& Riis, O. (Eds.). (2003). Religion in secularizing society: the Europeans' religion at the end of the 20th century. Leiden, Boston: Brill.

Hammond, P. E. (1992). Religion and personal autonomy: the third disestablishment in America. Columbia: University of South Carolina Press.

Hummer, R. A., Ellison, C. G., Rogers, R. G., Moulton, B. E., \& Romero, R. R. (2004). Religious involvement and adult mortality in the United States: review and perspective. Southern Medical Journal, 97(12), 1223-1230.

Inglehart, R. \& Norris, P. (2009) Muslim integration into Western Cultures: between origins and destinations. HKS Faculty Research Working Paper Series RWP09-007, John F. Kennedy School of Government, Harvard University.

Johnstone, R. L. (2008). Religion in society: a sociology of religion (8th ed.). New York: Routledge.

Kaufmann, E. (2010). Shall the religious inherit the earth: demography and politics in the $21^{\text {st }}$ century. London: Profile Books Ltd..

Kaufmann, E., Skirbekk, V., \& Goujon, A. (2010). Secularism, fundamentalism, or Catholicism? The religious composition of the United States to 2043. Journal for the Scientific Study of Religion, 49(2), 293-310.

Klotz, J., \& Gisser, R. (2015). Mortality differentials by religious denomination in Vienna 1981-2002. In VID working paper 8/2015. Vienna: Vienna Institute of Demography.

Knippenberg, H. (2010). Secularisation and the rise of immigrant religions: the case of the Netherlands. Acta Universitatis Carolinae. Geographical, 44(1-2), 63-82.

Kulu, H., Hannenmann, T., Pailhé, A., Neels, K., Krapf, S., González-Ferrer, A., \& Andersson, G. (2017). Fertility by birth order among the descendants of immigrants in selected European countries. Population and Development Review, 43(1), 31-60.

Lucassen, L., \& Laarman, C. (2009). Immigration, intermarriage and the changing face of Europe in the post war period. History of the Family, 14(2009), 52-68. 
Marzouki, N., Mcdonnell, D., \& Roy, O. (Eds.). (2016). Saving the people: how populists hijack religion. London: Hurst \& Company.

Mayer, J., \& Riphahn, R. T. (2000). Fertility assimilation of immigrants: evidence from count data models. Journal of Population Economics, 13(2), 241-261.

McQuillan, K. (2004). When does religion influence fertility? Population and Development Review, 30(1), 25-56.

Messina, A. M. (2007). The logics and politics of post-WWII migration to Western Europe. Cambridge: Cambridge University Press.

Mutchler, J. E., \& Burr, J. A. (2011). Race, ethnicity, and aging. In R. Settersten \& J. Angel (Eds.), Handbook of sociology of aging, Handbooks of Sociology and Social Research. New York: Springer.

Neumayer, E. (2005). Bogus refugees? The determinants of asylum migration to Western Europe. International Studies Quarterly, 49, 389-409.

PEW Research Center. (2011). Global Christianity. Available at: http://www.pewforum.org/2011/12/19 /global-christianity-exec/ (last accessed 13.02.2017).

PEW Research Center. (2012). The global religious landscape. Available at: http://www.pewforum.org/2012 /12/18/global-religious-landscape-exec/ (last accessed 13.02.2017).

Rogers, A. (Ed.). (1981). Advances in multiregional demography. IIASA research report. Laxenburg: International Institute for Applied Systems Analysis.

Rogers, A. \& Castro, J. (1982). Model schedules in multistate demographic analysis: the case of migration. Chapter 3, pp.113-154 in Land and Rogers 1982.

Statistik Austria (2016). Ergebnisse der Bevölkerungsprognose 2016. Vienna: Statistik Austria. Available at: http:/www.statistik.at/web_de/statistiken/menschen_und_gesellschaft/ bevoelkerung/demographische prognosen/bevoelkerungsprognosen/index.html (last accessed 28.02.2017).

Stonawski, M., Skirbekk, V., Kaufmann, E., \& Goujon, A. (2015). The end of secularization through demography? Projections of Spanish religiosity. Journal of Contemporary Religion, 30(1), 1-21.

Turner, B. S. (2011). Religion and modern society: citizenship, secularisation and the state. Cambridge: Cambridge University Press.

Van der Heijden, K. (1996). Scenarios: the art of strategic conversation. Chichester: Wiley.

Vertovec, S. (2007). Super-diversity and its implications. Ethnic and Racial Studies, 30(6), 1024-1054.

Zimmermann, K. F. (1995). Tackling the European migration problem. The Journal of Economic Perspectives, $9(2), 45-62$. 